\title{
Pacjent z wrodzonym blokiem przedsionkowo-komorowym i odelektrodowym zapaleniem wsierdzia
}

\section{Patient with congenital atrioventricular block and pacemaker lead endocarditis}

\author{
Szymon Olędzki, Andrzej Wojtarowicz, Jarosław Gorący \\ Klinika Kardiologii Pomorskiego Uniwersytetu Medycznego w Szczecinie
}

\section{Streszczenie}

Infekcyjne zapalenie wsierdzia obejmujące wszczepione urządzenie do elektroterapii serca stanowi coraz częstszy problem w praktyce klinicznej. Postępowania diagnostyczne i terapeutyczne w przypadku podejrzenia zakażenia związanego z urządzeniem wszczepialnym budzi wiele kontrowersji. W niniejszym artykule zaprezentowano historię choroby młodego pacjenta z wrodzonym blokiem przedsionkowo-komorowym III stopnia i implantowanym stymulatorem serca, u którego rozpoznano infekcyjne zapalenie wsierdzia z wegetacją na elektrodzie prawokomorowej. Leczenie chorego trwało 61 dni i wymagało interdyscyplinarnego postępowania z udziałem specjalistów zajmujących się: kardiologią zachowawczą, elektroterapią, mikrobiologią, kardiochirurgią i anestezjologią. Zdaniem autorów przypadek ten jest wart przedstawienia, zwłaszcza w kontekście zmian w wytycznych Europejskiego Towarzystwa Kardiologicznego dotyczących leczenia infekcyjnego zapalenia wsierdzia.

Słowa kluczowe: zapalenie wsierdzia, stymulator serca, blok przedsionkowo-komorowy

Folia Cardiologica 2016; 11, 5: 481-484

\section{Wstęp}

Szacuje się, że 0,5-4,8\% implantacji urządzeń do elektroterapii serca jest powikłanych infekcją, a pacjenci z wszczepialnymi urządzeniami stanowią około 9\% wszystkich chorych z infekcyjnym zapaleniem wsierdzia (CDRIE, cardiac device-related infective endocarditis) [1]. Brakuje szczegółowych informacji na temat częstości CDRIE w Polsce. Z danych Kliniki Kardiologii Uniwersytetu Medycznego w Lublinie wynika, że prawie co 3 przezżylne usunięcie elektrody wykonuje się z powodu infekcyjnego zapalenia wsierdzia (IZW) [2]. Większość przypadków CDRIE wywołana jest gronkowcami koaagulazoujemnymi (ok. 70\% dodatnich wyników posiewów), rzadziej izoluje się Staphylococcus aureus (ok. 14\% dodatnich posiewów), w około 30\% czynnik etiologiczny CDRIE jest nieznany [3, 4]. Odelektrodowe zapalenie wsierdzia wiąże się z wysoką śmiertelnością
- ocenia się, że $65 \%$ chorych leczonych zachowawczo umiera. Usunięcie urządzenia w połączeniu z optymalną antybiotykoterapią ogranicza śmiertelność do kilkunastu procent [5]. Wśród czynników ryzyka CDRIE wymienia się: cukrzyce, przewlekłą chorobę nerek, niewydolność serca, płeć męską, wcześniejsze interwencje (rewizje loży, wymiany urządzenia), obecność więcej niż dwóch elektrod oraz stosowanie czasowej stymulacji serca $[1,6,7]$.

\section{Opis przypadku}

Mężczyzna w wieku 31 lat został przyjęty na oddział kardiologii z powodu utrzymującej się od około 2 tygodni gorączki do $39,5^{\circ} \mathrm{C}$ ze zlewnymi potami i dreszczami. Pierwotnie gorączce towarzyszył ból gardła. Przed przyjęciem, w związku z podejrzeniem anginy paciorkowcowej, zgodnie z decyzją lekarza rodzinnego chory przyjmował klarytromycynę. 
Pacjent w 1996 roku miał implantowany dwujamowy układ stymulujący serce z powodu wrodzonego bloku przedsionkowo-komorowego III stopnia. Ze względu na wyczerpanie baterii stymulator wymieniano w 2004 roku i w czerwcu 2012 roku. Na początku 2013 roku wykonano rewizję loży z powodu ścieńczenia skóry nad korpusem urządzenia. Wówczas nie stwierdzono cech infekcji loży, a parametry stanu zapalanego były w granicach normy. Nie odnotowano wtedy istotnych odchyleń w przezklatkowym badaniu echokardiograficznym (TTE, transthoracic echocardiogram). Dwukrotnie, w maju 2013 i styczniu 2014 roku, pacjenta leczono antybiotykoterapią w związku z zaczerwienieniem nad korpusem urządzenia. Dodatkowo w 2012 roku u chorego rozpoznano migotanie przedsionków, które uznano za utrwalone z powodu braku skuteczności kardiowersji elektrycznej i braku objawów podmiotowych.

Przy przyjęciu pacjent, oprócz gorączki, skarżył się na osłabienie (negował ból gardła). Z odchyleń w badaniu przedmiotowym stwierdzono bladą, wilgotną skórę i szmer niedomykalności zastawki trójdzielnej. Nie odnotowano wykwitów skórnych, cech infekcji loży stymulatora, powiększonych węzłów chłonnych, odchyleń w badaniu jamy brzusznej i w badaniu neurologicznym. W echokardiografii przezklatkowej (TTE, transthoracic echocardiography) na wysokości zastawki trójdzielnej obserwowano balotujące echo o średnicy około $2 \mathrm{~cm}$, związane z elektrodą komorową (ryc. 1). Z odchyleń w badaniach laboratoryjnych stwierdzono: wysokie stężenie białka C-reaktywnego (CRP, C-reactive protein) równe $124 \mathrm{mg} / \mathrm{l}$ i prokalcytoniny $2,21 \mathrm{ng} / \mathrm{ml}$, leukocytozę (WBC, white blood cells) $17 \mathrm{G} / \mathrm{l}$, podwyższone stężenie kreatyniny w osoczu 1,09 mg/dl bez proteinurii oraz zwiększone miano czynnika reumatoidalnego. Nie wykazano odchyleń w badaniu rentgenograficznym (RTG) klatki piersiowej i ultrasonograficznym (USG) jamy brzusznej. Przy przyjęciu pobrano 3 próbówki krwi (w odstępie 30min.) z wkłuć obwodowych i wykonano posiewy w kierunku bakterii tlenowych, beztlenowych i grzybów, otrzymując po 5 dniach inkubacji wynik ujemny. Jednak na podstawie całości obrazu klinicznego u pacjenta rozpoznano CDRIE. Chorego leczono empirycznie: wankomycyną $30 \mathrm{mg} / \mathrm{kg} \mathrm{mc/}$ /dobę i.v. w 2 dawkach, gentamycyną $3 \mathrm{mg} / \mathrm{kg} \mathrm{mc/dobę}$ i.v. w 2 dawkach i rifampicyną $1200 \mathrm{mg}$ p.o. w 2 dawkach. Stężenie wankomycyny w surowicy monitorowano w ramach współpracy z Katedrą Farmakologii Pomorskiego Uniwersytetu Medycznego (PUM). Zgodnie z zaleceniem mikrobiologa szpitalnego zastosowano flukonazol w dawce $100 \mathrm{mg} /$ /dobę jako profilaktykę przeciwgrzybiczą (postępowanie nieuwzględnione w wytycznych Europejskiego Towarzystwa Kardiologicznego [ESC, European Society of Cardiology]). W ciągu 10 dni leczenia uzyskano ustąpienie dolegliwości, redukcję stężenia CRP (18 mg/l) oraz WBC (7,3 G/l). Pacjenta przekazano do I Kliniki Kardiologii Uniwersytetu Medycznego w Poznaniu w celu przezskórnego usunięcia układu stymulującego serce.

Po niepowikłanym zabiegu chorego przekazano powrotnie do Kliniki Kardiologii PUM. Posiewy z usuniętych elektrod były ujemne. W kontrolnym badaniu echokardiograficznym jednak stwierdzono obecność dodatkowego echa w prawym przedsionku o wymiarach około $12 \times 13 \mathrm{~mm}$ (ryc. 2). Dodatkowo po zabiegu obserwowano narastanie stężenia CRP (16 mg/l w 1. dobie po zabiegu, $50 \mathrm{mg} / \mathrm{l}$ w 4. dobie) oraz stwierdzono nowe zmiany zapalne w RTG klatki piersiowej. Mimo płynoterapii obserwowano pogorszenie funkcji nerek (wskaźnik filtracji kłębuszkowej [GFR, glomerular filtration rate] $53 \mathrm{ml} / \mathrm{min} / 1,73 \mathrm{~m}^{2}$ ). Ponieważ spadek filtracji kłębuszkowej mógł być spowodowany nefrotoksycznością zastosowanej terapii (ale także IZW per se), po konsultacji z mikrobiologiem szpitalnym odstawiono gentamycynę i wankomycynę, włączono meropenem $3 \mathrm{~g}$ i.v. w 3 dawkach. Pacjenta leczono kolejne 36 dni, uzyskując normalizację parametrów zapalnych, parametrów nerkowych i całkowite ustąpienie dolegliwości. W kontrolnych

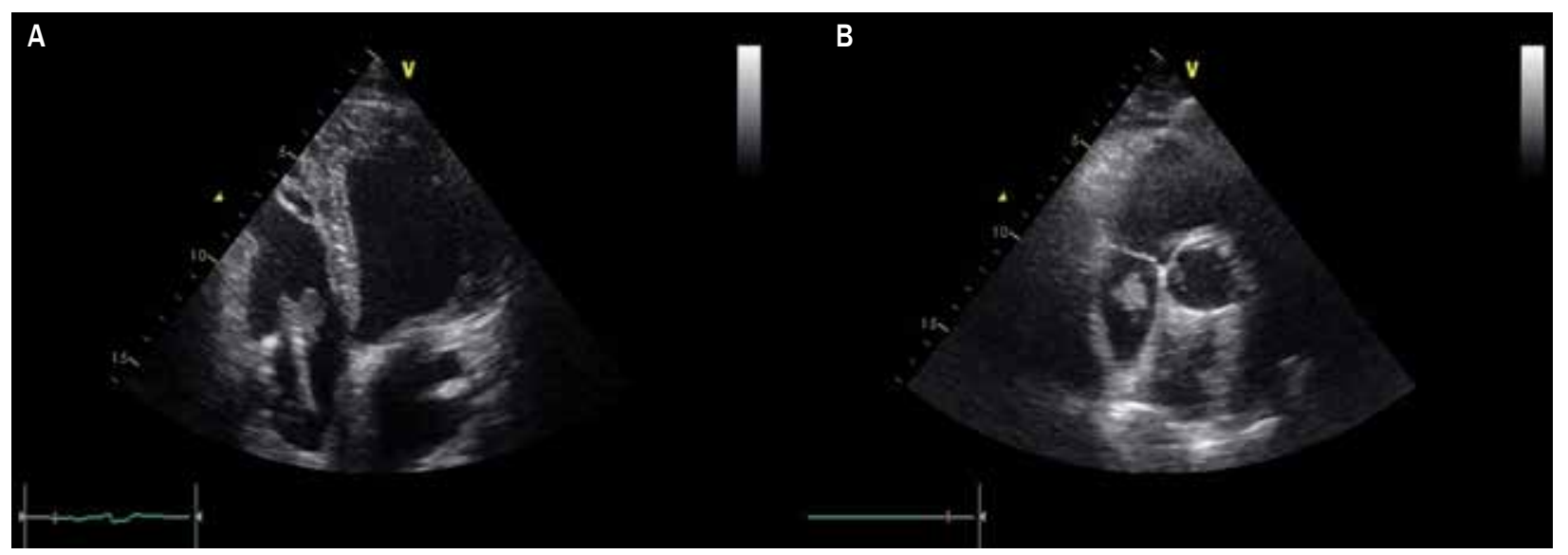

Rycina 1. Wegetacja na elektrodzie komorowej. A. Projekcja koniuszkowa czterojamowa. B. projekcja przymostkowa, oś krótka 


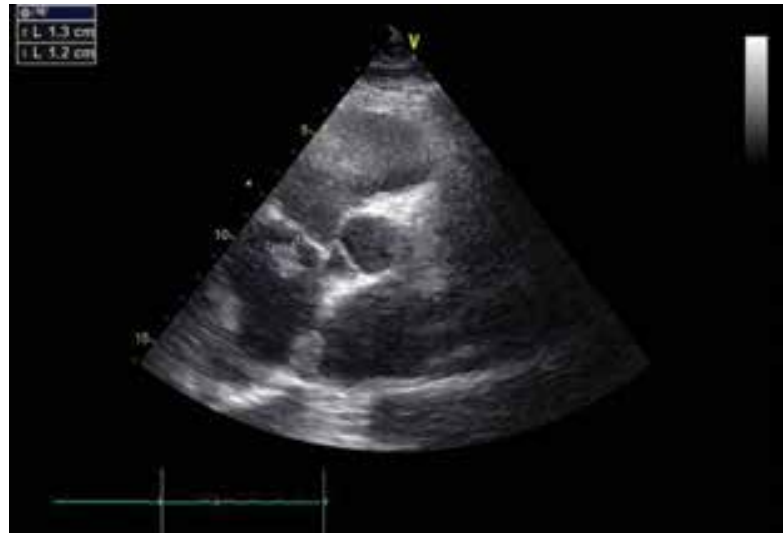

Rycina 2. Dodatkowe balotujące echo o wymiarach $13 \times 12 \mathrm{~mm}$ w prawym przedsionku

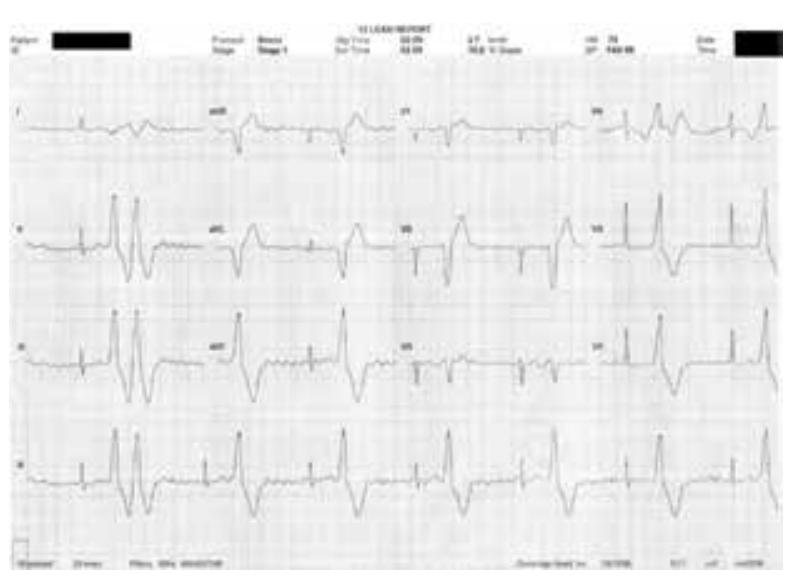

Rycina 3. Badanie EKG w trakcie próby wysiłkowej. Liczne komorowe pobudzenia dodatkowe: para i bigeminia komorowa

badaniach echokardiograficznych stwierdzano jednak obecność dodatkowego echa tak jak w badaniu wyjściowym (po usunięciu stymulatora). Pacjenta oceniono pod kątem konieczności implantacji kolejnego urządzenia. W EKG stwierdzono migotanie przedsionków z zastępczym rytmem węzłowym około 50/min. W badaniu EKG metodą Holtera nie obserwowano pauz powyżej 2,5 s, ale w próbie wysiłkowej EKG stwierdzono brak odpowiedzi chronotropowej oraz liczne dodatkowe pobudzenia komorowe indukowane wysiłkiem, w tym pary, bigeminię i trigeminię (ryc. 3). Przypadek pacjenta omawiano w ramach kilku spotkań Heart Team (interdyscyplinarnego zespołu kardiologów i kardiochirurgów), ostatecznie kwalifikując go do operacyjnego usunięcia zmiany w prawym przedsionku, podwiązania uszka lewego przedsionka oraz naszycia elektrody nasierdziowej i implantacji stymulatora serca w powłoki brzuszne.

Po leczeniu kardiochirurgicznym, które przebiegło bez powikłań, chorego przekazano do kliniki kardiologii. Posiewy wykonane z materiału uzyskanego w trakcie operacji były ujemne. Po kolejnych 10 dniach leczenia pacjent w stanie dobrym został wypisany do domu.

Czas obserwacji chorego od chwili rozpoznania IZW obecnie wynosi 2 lata. Nie odnotowano u pacjenta ponownych epizodów infekcji związanych z urządzeniem do elektroterapii. Pacjent jest w pełni sprawny i prowadzi satysfakcjonujące życie zawodowe i rodzinne.

\section{Omówienie}

Obecnie obserwuje się wzrost liczby infekcji związanych z wszczepialnymi urządzeniami do elektroterapii serca [1]. Z danych amerykańskich wynika, że CDRIE w 2008 roku odnotowano u 2,41\% chorych z urządzeniami wszczepialnymi. W 2004 zaś liczba ta była mniejsza o 0,88\% [8]. Należy się zatem spodziewać coraz częstszych trudności klinicznych związanych z CDRIE.

$\mathrm{U}$ przedstawianego pacjenta kolejne posiewy z krwi, elektrody i materiału uzyskanego podczas operacji były ujemne. Brak izolacji patogenu wynikał zdaniem autorów z rozpoczęcia antybiotykoterapii na etapie przedszpitalnym. Pacjent spełniał jednak kryteria rozpoznania pewnego IZW według zmodyfikowanych kryteriów Duke’a (wegetacje w echokardiografii, predysponujący stan, gorączka, czynnik reumatoidalny). Uwzględniając znane uwarunkowania epidemiologiczne w szpitalu, po konsultacji z lekarzem mikrobiologiem zdecydowano się odstąpić od kosztownej diagnostyki serologicznej oraz diagnostyki metodami biologii molekularnej. Postępowanie to było zgodne z algorytmem diagnostyki mikrobiologicznej zaproponowanym w wytycznych ESC dotyczących IZW z 2009 roku. Według obecnych wytycznych powinna być wykonana dodatkowa diagnostyka [4]. Wiedząc, że w ośrodku prowadzącym leczenie zdecydowanie najczęściej izolowanym patogenem z zainfekowanych elektrod jest Staphylococsus epidermidis oraz że kolejne miejscowe powikłania pojawiały się w odstępach poniżej 12 miesięcy od poprzedniego leczenia, zastosowano schemat antybiotykoterapii empirycznej dla wczesnego zakażenia sztucznej zastawki według wytycznych z 2009 roku. Leczenie zmodyfikowano głównie ze względu na nefrotoksyczność terapii, objawiającą się spadkiem filtracji kłębuszkowej. W związku z szerokim spektrum przeciwbakteryjnym oraz brakiem działania nefrotoksycznego choremu podano meropenem.

Pacjent z urządzeniem wszczepialnym, wysoko gorączkujący, powinien zawsze budzić podejrzenie IZW, zwłaszcza jeśli jest obciążony wywiadem w kierunku przebytych powikłań w obrębie loży. Skierowanie omawianego pacjenta do szpitala przed włączeniem antybiotyku być może pozwoliłoby na izolację drobnoustroju i zastosowanie antybiotykoterapii celowanej. Badaniem podstawowym w diagnostyce IZW jest TTE (klasa zaleceń I), które dostępne jest przez całą dobę na większości oddziałów kardiologicznych. W opisywanym przypadku TTE ujawniło u chorego typowe dla IZW zmiany (wegetację). W świetle wytycznych ESC z 2015 roku 
TTE powinno być uzupełnione przezprzełykowym badaniem echokardiograficznym (TEE, transesophageal echocardiography) u chorego ze sztucznym materiałem w sercu. W starszej wersji wytycznych TEE nie było bezwzględnie zalecane w przypadku obecności jednoznacznych zmian w TTE. U omawianego pacjenta, ze względu na lokalizacje IZW w prawej części serca, rozważano wykonanie wielorzędowej tomografii komputerowej, która pozwala na stwierdzenie towarzyszących zmian w płucach. Odstąpiono jednak od badania z powodu nefrotoksyczności kontrastu oraz niewielkiego znaczenia w kontekście zaplanowanej terapii.

Analizując historię choroby pacjenta, można przypuszczać, że decyzja o usunięciu układu stymulującego serce na etapie miejscowych powikłań mogła zapobiec IZW. Obecnie ESC zaleca usuwanie całości urządzenia nie tylko w przypadku CDRIE, ale także w przypuszczalnie izolowanej infekcji loży, co jest nowością w stosunku do wytycznych z 2009 roku. Preferuje się usunięcie urządzenia metodą przezskórną. Chirurgiczne usunięcie układu należy rozważyć w przypadku braku możliwości usunięcia całości droga przezskórną lub dużego uszkodzenia zastawki trójdzielnej oraz można rozważyć w przypadku dużych wegetacji powyżej 20 mm (> 25 mm według wytycznych z 2009 r.).

U każdego chorego po usunięciu urządzenia do elektroterapii serca z powodu infekcji należy starannie rozważyć wskazania do ponownej implantacji. Pacjent ze względu na całkowity blok przedsionkowo komorowy wymagał wszczepienia stymulatora serca. Ostatecznie implantowano mu elektrodę nasierdziową. Mimo zalet nasierdziowej stymulacji lewokomorowej postępowanie to było konsekwencją leczenia kardiochirurgicznego IZW [9]. Brakuje obecnie zaleceń dotyczących sposobu implantacji stymulatora po CDRIE (implantacja elektrody nasierdziowej w różnych sytuacjach klinicznych była niejednokrotnie wybierana w ośrodku autorów, omówienie zagadnienia jednak wykracza poza ramy niniejszego artykułu).

\section{Konflikt interesów}

Autorzy deklarują brak konfliktu interesów.

\section{Abstract}

Infective endocarditis affecting cardiac implantable electronic device is life-threatening condition. Its incidence increased lately. Diagnostic and therapeutic proceedings in case of infective endocarditis may be difficult. We present a case of young male with pacemaker implanted for congenital third degree atrioventricular block who developed infective endocarditis with right ventricular lead vegetation. The patient was treated for 61 days with the participation by interdisciplinary team inckuding specialists in conservative cardiology, electrotherapy devices, microbiology, cardiac surgery and anesthesiology. In our opinion the case appears worthy of a wider discussion, especially considering the new European Society of Cardiology guidelines for the management of infective endocarditis.

Key words: endocarditis, pacemaker, atrioventricular block

Folia Cardiologica 2016; 11, 5: 481-484

\section{Piśmiennictwo}

1. Ann H.W., Ahn J.Y., Jeon Y.D. i wsp. Incidence of and risk factors for infectious complications in patients with cardiac device implantation. Int. J. Infect. Dis. 2015; 36: 9-14.

2. Kutarski A., Czajkowski M., Pietura R. i wsp. Zabiegi przezżylnego usuwania elektrod z zastosowaniem systemów mechanicznych. Analiza doświadczeń ekstrakcji 2574 elektrod u 1536 pacjentów. Kardiol. Pol. 2014; 73 (supl. III): 112-113.

3. Bongiorni M.G., Tascini C., Tagliaferri E. i wsp. Microbiology of cardiac implantable electronic device infections. Europace 2012; 14: 1334-1339.

4. Habib G., Lancellotti P., Antunes M.J. i wsp. Wytyczne ESC dotyczące leczenia infekcyjnego zapalenia wsierdzia w 2015 roku. Kardiol. Pol. 2015; 73: 963-1027.

5. Domańska E., Witkowska A., Kaliciński Z. i wsp. Infekcyjne zapalenie wsierdzia w wyniku zakażenia pięciu elektrod układu stymulującego serce - diagnostyka i postępowanie terapeutyczne. Kardiochir. Torakochir. Pol. 2012; 1: 95-99.
6. Hercé B., Nazeyrollas P., Lesaffre F. i wsp. Risk factors for infection of implantable cardiac devices: data from a registry of 2496 patients. Europace 2013; 15: 66-70.

7. Nery P.B., Fernandes R., Nair G.M. i wsp. Device-related infection among patients with pacemakers and implantable defibrillators: incidence, risk factors, and consequences. J. Cardiovasc. Electrophysiol. 2010; 2: 786-790.

8. Greenspon AJ., Patel J.D., Lau E. i wsp. 16-year trends in the infection burden for pacemakers and implantable cardioverter-defibrillators in the United States 1993 to 2008. J. Am. Coll. Cardiol. 2011; 58: 1001-1006.

9. Bartczak K., Ammer A., Bartczak M. i wsp. Implantation of VVI epicardial pacemaker through mini-sternotomy in a patient with superior vena cava occlusion after radiotherapy. Kardiochir. Torakochir. Pol. 2014; 11: 69-70. 


\section{Komentarz}
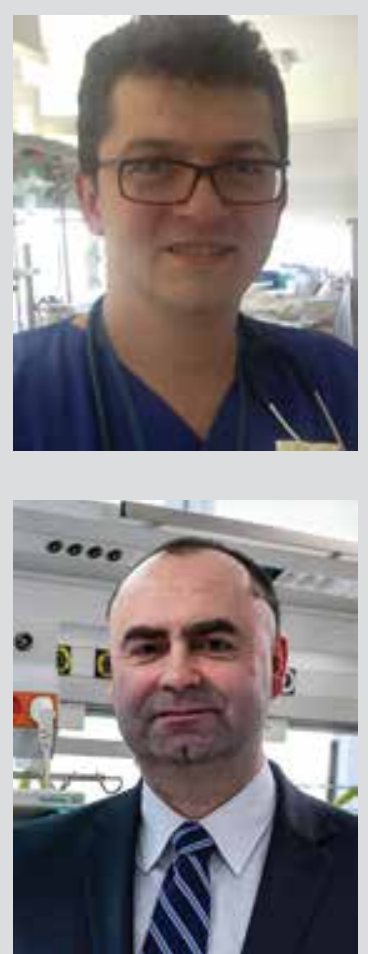

dr n. med. Radosław Jaworski ${ }^{1}$, dr hab. n. med. Ireneusz Haponiuk $k^{1,2}$

${ }^{1}$ Oddział Kardiochirurgii Dziecięcej, Szpital im. Św. Wojciecha w Gdańsku-Zaspie

${ }^{2}$ Katedra Fizjoterapii, Wydział Rehabilitacji i Kinezjologii

Akademii Wychowania Fizycznego i Sportu im. Jędrzeja Śniadeckiego w Gdańsku

Wrodzony blok przedsionkowo-komorowy (CAVB, congenital atrio-ventricular block) jest rzadką wadą układu przewodzącego (1/22 000 żywo urodzonych), u której podłoża leży płodowe uszkodzenie struktur bodźcotwórczych serca. U 25-33\% pacjentów CAVB towarzyszy strukturalnej wrodzonej wadzie serca. Problem izolowanego CAVB najczęściej dotyczy dzieci matek z chorobami autoagresyjnymi (toczeń trzewny lub zespół Sjögrena) z potwierdzonymi przeciwciałami w okresie ciąży. U płodów z CAVB, poza zwolnionym rytmem serca, w badaniu metodą echokardiografii płodowej rozpoznaje się objawy niewydolności serca, często bardzo nasilone, mogące prowadzić do przedwczesnego zgonu (19-31\% płodów). Z tego powodu obecnie leczenie najczęściej rozpoczyna się już w okresie życia płodowego - matce podaje się leki o penetracji łożyskowej (betametazon), z perspektywą niezbędnej stałej elektrostymulacji serca, często już w okresie noworodkowo-niemowlęcym, i kontynuuje się ją przez całe życie [1].

W pracy przedstawiono przypadek 31-letniego mężczyzny, u którego rozpoznano infekcyjne zapalenie wsierdzia (IZW) związane z wszczepionym dwujamowym układem stymulującym serce z powodu wrodzonego bloku przedsionkowo-komorowego III stopnia [2]. W wykonanym przezklatkowym badaniu echokardiograficznym (TTE, transthoracic echocardiography) w polu zastawki trójdzielnej obserwowano wegetację związaną z elektrodą prawokomorową. Mimo wielokrotnie wykonywanych badań mikrobiologicznych nie udało się ustalić czynnika etiologicznego zakażenia. W pracy szczegółowo opisano diagnostykę, strategię leczenia wraz z zastosowaną farmakoterapią, z osiągniętym sukcesem terapeutycznym popartym odległą obserwacją.

Autorzy omówili aktualizację opublikowaną w 2015 roku wytycznych ESC z 2009 roku dotyczących opisywanej jednostki chorobowej [3, 4]. Należy podkreślić, że w przypadku podejrzenia IZW związanego z wszczepionymi urządzeniami obecnie zaleca się wykonywanie echokardiografii przezprzełykowej (TEE, transesophageal echocardiography). Dodatkowo, warto zwrócić uwagę, że we wszystkich przypadkach IZW wymagających leczenia chirurgicznego zaleca się wykonanie śródoperacyjnego badania echokardiograficznego w celu określenia dokładnej lokalizacji i zakresu zakażenia (klasa zaleceń I B) [3].

W aktualnych wytycznych dotyczących diagnostyki i leczenia IZW podkreśla się konieczność pobierania co najmniej 3 próbek krwi w 30-minutowych odstępach w celu wykonania badań mikrobiologicznych każda powinna zawierać po $10 \mathrm{ml} \mathrm{krwi,} \mathrm{na} \mathrm{podłoże} \mathrm{tlenowe} \mathrm{oraz} \mathrm{beztlenowe.} \mathrm{Próbki} \mathrm{krwi} \mathrm{powinny} \mathrm{być} \mathrm{pobierane} \mathrm{z} \mathrm{oddzielnych} \mathrm{wkłuć} \mathrm{do} \mathrm{naczyń}$ obwodowych, ponieważ w przypadku pobrania z centralnych dostępów dożylnych występują wyższe ryzyko zanieczyszczenia i związana z tym błędna interpretacja wyników.

W większości IZW związanych z urządzeniami wszczepialnymi czynnikami etiologicznymi zakażenia są gronkowce, wśród których do 50\% stanowią szczepy metycylinooporne. We wstępnym leczeniu empirycznym do czasu uzyskania wyników badań mikrobiologicznych zalecane jest stosowanie wankomycyny [5]. Należy podkreślić, że podawanie kloksacyliny lub cefazoliny w leczeniu IZW spowodowanego gronkowcami złocistymi wrażliwymi na metycylinę (MSSA, methicillin-sensitive Staphylococcus aureus) wiąże się z niższym współczynnikiem śmiertelności w porównaniu z leczeniem innymi antybiotykami beta-laktamowymi. Obserwacja ta dotyczy terapii amoksycyliną z kwasem klawulonowym i ampicyliną z sulbaktamem oraz - co istotne - także z wankomycyną [3].

Na uwagę zasługuje również przedstawiona przez Autorów właściwa interpretacja badań laboratoryjnych, w naszej ocenie niezwykle ważna zwłaszcza u chorych po zabiegach operacyjnych. Narastanie stężenia białka C-reaktywnego (CRP, C-reactive protein) w pierwszych 48 godzinach po zabiegu związane jest z reguły z naturalną kinetyką tego mediatora w organizmie człowieka w odpowiedzi na odczyn zapalny związany z operacją czy interwencją. Podwyższone stężenie CRP w tym okresie najczęściej nie wiąże się z rozwojem bądź też nasilaniem objawów zakażenia. Istotna jest natomiast 
obserwacja trendu zmian stężenia tego białka w kolejnych dobach pooperacyjnych, począwszy od 2. doby po zabiegu - bez względu na zawartość osoczowego CRP w 2. dobie pooperacyjnej jej zwiększenie w kolejnej stanowi istotną informację kliniczną sugerującą konieczność włączenia terapii lub zmiany dotychczas podawanego antybiotyku. Natomiast zdecydowane zmniejszenie CRP od 2. doby wskazuje, że wysokie wartości CRP nie mają związku z zakażeniem [6].

Podsumowując, należy zauważyć, że podobnie jak zasadniczy problem prezentowanego pacjenta - CAVB, także odelektrodowe IZW nadal są chorobami potencjalnie śmiertelnymi. Zasadniczo złe rokowanie w IZW związanym z obecnością wszczepialnych urządzeń do elektroterapii serca prawdopodobnie wiąże się z częstszym występowaniem choroby u osób w podeszłym wieku i pacjentów z licznymi towarzyszącymi problemami [3]. Należy mieć nadzieję, że coraz liczniejsze doniesienia o skutecznej terapii IZW, w oparciu o dalszy rozwój diagnostyki i doskonalenie metod terapii, będzie skutkowało oczekiwaną poprawą rokowania [7, 8]. Przedstawiony opis zakończonego sukcesem leczenia odelektrodowego IZW jest cennym uzupełnieniem aktualnej wiedzy dotyczącej zapalenia wsierdzia związanego z urządzeniami wszczepialnymi i podkreśla pozytywną wartość interdyscyplinarnej współpracy zespołu lekarzy różnych specjalizacji.

\section{Piśmiennictwo}

1. Haponiuk I., Chojnicki M., Szofer-Sendrowska A. i wsp. 'Planned' permanent pacemaker implantation in one-day old newborn after prenatal diagnosis of congenital heart block. Kardiochir. Torakochir. Pol. 2014; 11: 76-78.

2. Olędzki S., Wojtarowicz A., Gorący J. Pacjent z wrodzonym blokiem przedsionkowo-komorowym i odelektrodowym zapaleniem wsierdzia. Folia Cardiol. 2016; 11: 481-484.

3. Habib G., Lancellotti P., Antunes M.J. i wsp. Wytyczne ESC dotyczące leczenia infekcyjnego zapalenia wsierdzia w 2015 roku. Kardiol. Pol. 2015; 73: 963-1027.

4. Habib G., Hoen B., Toros P. i wsp. Wytyczne dotyczące zapobiegania, rozpoznawania i leczenia infekcyjnego zapalenia wsierdzia (nowa wersja - 2009). Kardiol. Pol. 2010; 68: S1-S52.

5. Bongiorni M.G., Tascini C., Tagliaferri E. i wsp. Microbiology of cardiac implantable electronic device infections. Europace 2012; 14: 1334-1339.
6. Jaworski R., Haponiuk I., Irga-Jaworska N. i wsp. Kinetics of C-reactive protein in children with congenital heart diseases in the early period after cardiosurgical treatment with extracorporeal circulation. Adv. Med. Sci. 2014; 59: 19-22.

7. Jedlinski I.M., Bugajski P., Greberski K., Kalawski R., Slomczynski M. Infekcyjne zapalenie wsierdzia u chorego z wszczepionym układem stymulującym skutecznie leczone antybiotykami: obserwacja dwuletnia. Kardiol. Pol. 2014; 72: 386.

8. Bartczak K., Walczak A., Jander S. i wsp. Implantation of an epicardial lead through mini-thoracotomy as an alternative for patients with lead-related endocarditis who require permanent pacing. Kardiochir. Torakochir. Pol. 2013; 10: 62-66. 